\title{
RANCANG BANGUN SIMULASI TOOL SISTEM AUDIT TEKNOLOGI INFORMASI BERBASIS WEB
}

\author{
Cecep Kurnia Sastradipraja \\ Program Studi Sistem Informasi, Universitas Nusa Putra \\ Email: cecep.kurnia@nusaputra.ac.id \\ * Korespondensi: e-mail: cecep.kurnia@ nusaputra.ac.id
}

\begin{abstract}
ABSTRAK
Pada saat ini masih banyak ditemukan dalam melakukan proses audit masih menggunakan metode manual dalam lingkup pemrosesan data elektronik, salah satu dampaknya yaitu dapat mengurangi efektivitas dan efisiensi setiap tahap audit dan manajemen audit secara keseluruahan. Adapun tujuan dari penelitian ini adalah untuk menghasilkan prototipe berdasarkan rancang bangun simulasi tool sistem audit teknologi informasi yang dapat melakukan uji validasi kesesuaian antara penetapan standar mutu dengan hasil evaluasi, sekaligus memberikan informasi rekomendasi dan penilaian. Adapun tujuan penelitian adalah membuat rancang bangun simulasi tool sistem audit teknologi informasi berbasis website dengan menggunakan bahasa pemograman PHP serta MySQL sebagai sistem manajemen basis datanya. Untuk metodologi yang digunakan dalam pengembangan sistem menggunakan model waterfall. Prototipe dari dibangunnya simulasi tool sistem audit teknologi informasi diharapkan dapat membantu auditor dalam melakukan evaluasi dan analisis atas penilaian dari setiap temuan. Dari hasil pengujian rancang bangun simulasi tool sistem audit teknologi informasi berbasis web, didapatkan hasil semua fungsi sistem dapat berjalan dengan baik dan sesuai dengan yang diharapkan.
\end{abstract}

Kata kunci : Audit, Prototipe, Standar Mutu, Rekomendasi, Evaluasi

\begin{abstract}
ABSTRACS
At this time, there is still a lot to be found in the audit process still using the manual method within the scope of electronic data processing, one of the impacts can reduce the effectiveness and efficiency of each level of audit and audit management keseluruahan. The purpose of this research is to produce prototypes based on the design of simulation tools of information technology audit system that can conduct the conformity validation Test between the determination of quality standards with evaluation result, as well as Provide recommendation and assessment information. The purpose of research is to create a design and simulation of the system of Information Technology audit tool based website using PHP programming language as well as MySQL as its database management system. For methodologies used in system development using waterfall model. Prototype of the built-up simulation tool information technology auditing system is expected to assist auditors in conducting evaluation and analysis on the assessment of each findings. From the test results of the design build simulation of the system of Web-based information technology audits, obtained the results of all the functions of the system can run well and as expected.
\end{abstract}

Keywords: auditing, prototyping, quality standards, recommendation, evaluation

\section{PENDAHULUAN}

Suatu organisasi perlu melakukan pelaporan audit terhadap pihak-pihak yang berkepentingan baik itu pihak internal perusahaan maupun pihak-pihak eksternal perusahaan itu sendiri. Usaha untuk menilai beberapa hal seperti keandalan laporan, efektivitas dan efisiensi, serta kepatuhan terhadap aturan merupakan area-area yang menjadi cakupan proses audit. Dari berbagai area proses audit itulah akhirnya muncul istilah-istilah audit financial, audit operasional, dan audit kepatuhan. Dalam era globalisasi saat ini kemampuan mengolah data dengan komputer atau teknologi sejenisnya sangat dibutuhkan di dunia kerja, tidak terkeculi dalam pekerjaan audit. Para auditor diharapkan mampu mengolah dokumen digital sebagai data dengan bantuan komputer untuk menemukan bukti dan 
menghasilkan rekomendasi serta opini audit yang akurat. Teknik audit berbantuan komputer sendiri adalah setiap penggunaan teknologi informasi sebagai alat bantu dalam melakukan audit, sebaliknya audit konvensional merupakan bentuk lama, dimana proses audit tidak menggunakan alat teknologi.

Teknik audit berbantuan komputer, merupakan teknik modern dimana setiap pekerjaannya ditunjang dengan teknologi, hal ini tentu akan memberikan keuntungan baik bagi pihak auditor ataupun auditee, selain menghemat waktu tentunya, teknik audit berbantuan komputer juga mampu meningkatkan akurasi atas opini yang diberikan oleh seorang auditor, sehingga hal tersebut akan membantu auditee dalam meningkatkan kualitas pekerjaannya dikemudian hari. Perkembangan sistem informasi berbasis komputer saat ini tidak hanya digunakan sebagai alat pengolahan informasi, tetapi berfungsi sebagai alat pendukung dalam pengambilan keputusan. Perubahan dan perkembangan TI memberikan implikasi penting bagi aktivitas audit, diantaranya adalah kemampuan auditor melaksanakan proses percepatan dalam rangka akselerasi audit dan mampu mengerjakan audit yang sifatnya real time.

Teknik audit berbantuan komputer adalah pelaksanaan pengumpulan atau evaluasi bukti audit dengan menggunakan komputer. ${ }^{[1]}$ Sumber paket perangkat lunak audit dengan berbantuan komputer dapat menggunakan perangkat lunak paket (package software), perangkat lunak audit umum (general audit software), pesanan (customize) atau bahkan berbantuan perangkat lunak vendor dari microsoft seperti excell. Pendekatan pada audit berbantuan komputer, audit dilakukan dengan menggunakan komputer atau perangkat lunak audit untuk menunjang aktivitas pemeriksaan. Pendekatan audit berbantuan komputer merupakan teknik audit yang bermanfaaat dalam pengujian substantif (subtantive test) dan evaluasi keandalan atas file atau data enterprise.

Penelitian ini bertujuan membuat rancang bangun berupa prototipe simulasi tool sistem audit teknologi informasi berbasis web, yang sekiranya bisa menjadi tool dalam melakukan aktivitas audit berbantuan komputer dalam hal mengevaluasi, mengoreksi, menilai serta dapat memberikan akselerasi terhadap pelaporan atas temuan dan saran perbaikan yang dibutuhkan oleh auditor dan auditee.

\section{TINJAUAN PUSTAKA}

\subsection{Rancang Bangun}

Rancang bangun merupakan serangkaian prosedur untuk menerjemahkan hasil analisis dari sebuah sistem ke dalam bahasa pemrograman untuk mendeskripsikan dengan detail bagaimana komponen-komponen sistem diimplemantasikan. Sedangkan pengertian bangun atau pembangunan sistem adalah kegiatan menciptakan baru maupun mengganti atau memperbaiki sistem yang telah ada baik secara keseluruhan maupun sebagian. ${ }^{[2]}$

Mengutip dari Tata Sutabri, "Tahap rancangan sistem merupakan prosedur untuk mengkonversi spesifikasi logis ke dalam sebuah desain yang dapat diimplementasikan pada sistem komputer organisasi. Dimana tahap rancangan sistem dibagi menjadi dua bagian yaitu rancangan sistem secara umum dan rancangan secara rinci." ${ }^{[3]}$

\subsection{Sistem}

Sistem menurut Jogiyanto ${ }^{[4]}$ adalah suatu jaringan kerja prosedur-prosedur yang saling berhubungan, berkumpul bersama-sama untuk melakukan suatu kegiatan atau untuk menyelesaikan suatu sasaran yang tertentu. Mc.Leod ${ }^{[5]}$ menyatakan, sistem adalah himpunan dari unsur-unsur yang saling berkaitan sehingga membentuk suatu kesatuan yang utuh dan terpadu. Kristanto [6] mendefinisikan sistem hampir serupa dengan yang disampaikan Jogiyanto. Sistem adalah jaringan kerja dari prosesdur-prosedur yang saling berhubungan, berkumpul bersama-sama untuk melakukan 
suatu kegiatan atau menyelesaikan suatu sasaran tertentu. Sistem juga merupakan kumpulan elemenelemen yang saling terkait dan bekerja untuk memproses masukan (input) yang ditujukan kepada sistem tersebut dan mengolah masukan tersebut sampai menghasilkan keluaran (Output) yang diinginkan.

\subsection{Audit Sistem Informasi}

Definisi Audit sistem informasi (atau beberapa kalangan lebih menyukai untuk menyebut audit teknologi informasi) dapat dikemukakan sebagai berikut: ${ }^{[7]}$

a. Audit Sistem Informasi menurut Ron Weber (1999, p.10) adalah proses pengumpulan dan pengevaluasian bukti-bukti untuk menentukan apakah suatu sistem aplikasi komputerisasi telah menetapkan dan menerapkan sistem pengendalian intern yang memadai.

\section{b. ISACA-CISA Review Manual}

"Proses pengumpulan dan evaluasi bukti untuk menentukan apakah sistem informasi dan lingkungan teknologi informasi secara memadai melindungi aset, menjaga data dan integritas sistem, memberikan informasi yang relevan dan dapat dihubungkan, mencapai tujuan organisasi secara efektif, mengonsumsi sumber daya secara efisien, dan memiliki efek pengendalian internal yang menyediakan jaminan yang masuk akal bahwa tujuan operasional dan kontrol akan terpenuhi."

Apabila dilihat dari definisi-definisi diatas, maka dapat disimpullkan bahwa tujuan audit sistem informasi adalah untuk menilai apakah pengendalian sistem informasi telah dapat memberikan keyakinan yang memadai atas Pengamanan Asset, Integritas Data, Efektivitas, dan Efisiensi.

\subsection{PHPWebSite}

"phpWebSite adalah sebuah web content management, sebuah sistem opensource pembuat halaman web yang mampu mengendalikan isi dari web tersebut dan memudahkan dalam mengatur secara interaktif. Banyak sekali kelebihan-kelebihan phpWebSite dibandingkan dengan content management yang lain. Seperti halnya tdak perlu lagi mengubah website lama yang telah dibuat dengan format HTML tetapi bisa langsung diunggah kedalam phpWebSite sehingga menjadi satu bagian dari portal phpWebSite. Kelebihan yang lain adalah bisa membuat suatu fungsi baru yang dapat disesuaikan dengan tampilan yang diinginkan pada website yang dibangun." [8]

\subsection{Pengujian BlackBox}

Pengujian sistem perangkat lunak adalah bagian dari siklus hidup tesebut melibatkan verifikasi apakah setiap unit yang dikembangkan telah memenuhi kebutuhan sistem yang didefinisikan pada tahap sebelumnya. Salah satu metode pengujian unit yaitu blackbox testing, dimana blackbox testing berfokus pada apakah unit program memenuhi kebutuhan yang disebutkan dalam spesifikasi. Pada blackbox testing, cara pengujian hanya dilakukan dengan menjalankan atau mengeksekusi unit atau modul, kemudian diamati apakah hasil dari unit itu sesuai dengan proses bisnis yang diinginkan. Jika ada unit yang tidak sesuai outputnya, maka untuk menyelesaikannya diteruskan pada pengujian yang kedua, yaitu whitebox testing. ${ }^{[9]}$

\section{METODOLOGI PENELITIAN}

Rancang bangun simulasi tool sistem audit teknologi informasi yang akan dibuat menggunakan waterfall model. Pada tahapan ini menjelaskan urutan dan langkah-langkah yang dilakukan secara sistematis dalam menyelesaikan penelitian, seperti tertuang pada gambar 1 berikut ini: 


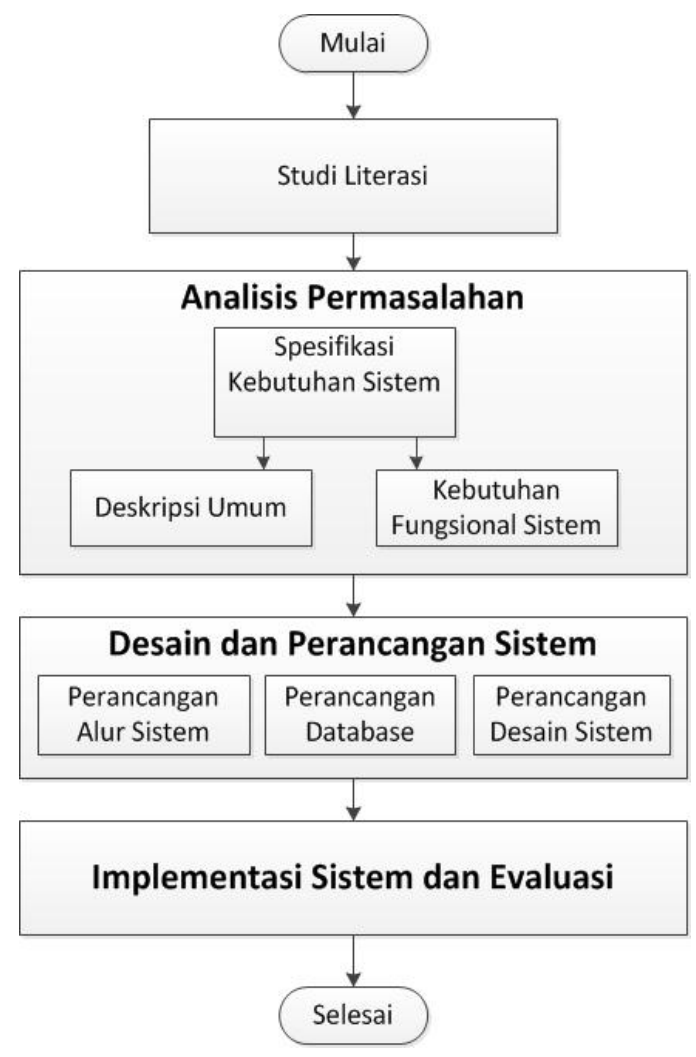

Gambar 1 Tahapan penelitian

Deskripsi tahap pengembangan, yaitu sebagai berikut:

1. Studi Literatur, Pada tahap ini yaitu mempelajari dokumen yang relevan dengan penelitian yang akan dilakukan.

2. Tahap Analisis, Pada tahapan ini, Mendefinisikan masalah untuk menentukan ruang lingkup sistem yang akan dibangun, serta memetakan spesifikasi kebutuhan sistem.

3. Tahap Desain, Tujuan pada tahapan ini adalah untuk memberikan gambaran apa yang seharusnya dikerjakan dan bagaimana tampilan User interface. Fase ini membantu menspesifikasikan kebutuhan perangkat keras dan sistem serta mendefinisikan arsitektur sistem secara keseluruhan.

4. Tahap Pengkodean, Pada tahap ini dilakukan pemograman. Konsep sistem audit teknologi informasi yang akan dibangun bersifat sederhana dan mudah difahami pengguna. Aplikasi yang dibangun berbasis web menggunakan bahasa pemrograman PHP dan MySQL sebagai Database Management System.

5. Tahap Pengujian, Pada tahapan ini meliputi proses penerapan sistem yang dibangun.

\section{HASIL DAN PEMBAHASAN}

Pada saat ini masih banyak ditemukan dalam melakukan proses audit masih menggunakan metode manual dalam lingkup pemrosesan data elektronik, salah satu dampaknya yaitu dapat mengurangi efektivitas dan efisiensi setiap tahap audit dan manajemen audit secara keseluruahan. Adapun tujuan dari penelitian ini adalah untuk menghasilkan prototipe berdasarkan rancang bangun simulasi tool sistem audit teknologi informasi yang dapat melakukan uji validasi kesesuaian antara penetapan standar mutu dengan hasil evaluasi, sekaligus memberikan informasi rekomendasi dan penilaian. 
Adapun tujuan penelitian adalah membuat rancang bangun simulasi tool sistem audit teknologi informasi berbasis website dengan menggunakan bahasa pemograman PHP serta MySQL sebagai sistem manajemen basis datanya.

\subsection{Perancangan Sistem}

Perancangan sistem dimulai dengan menspesifikasikan kebutuhan sistem, membuat flowchart diagram, diagram VTOC, dan struktur basis data.

\subsubsection{Diagram Alir Dokumen (Flowchart document)}

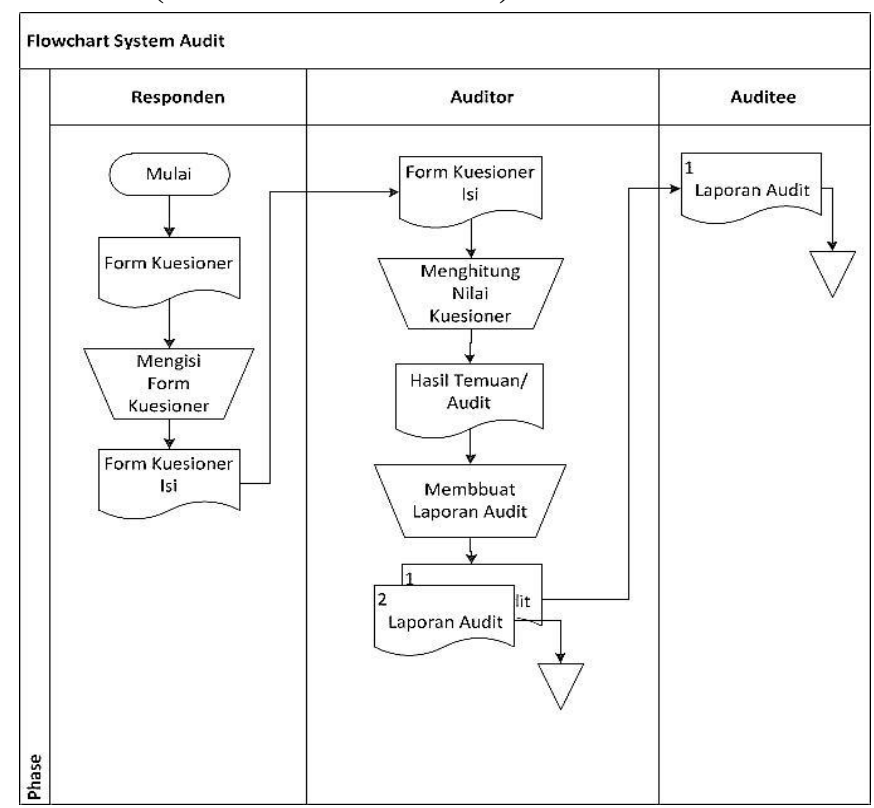

Gambar 2 Flowchart Dokumen Audit

Berikut ini adalah deskripsi dari Flowchart dokumen berjalan diatas; Dimulai saat auditor memberikan form auditee kepada auditee untuk mengisi kelengkapan audit, kemudian from dikembalikan ke auditor untuk di analisa dan identifikasi bisnis goal, dan auditor memetakan proses TI dari bisnis goal. Auditor membuat pertanyaan kuisioner sesuai proses TI yang terpilih, auditee menerima pertanyaan kuisioner dan mengisi kuisioner kemudian form kuisioner diberikan ke auditor untuk merekap nilai hasil kuisioner dan auditor menghitung hasil nilai kuisioner. Auditor membuat laporan hasil audit dan diberikan ke auditee.

\subsubsection{Diagram VTOC Aplikasi Audit}

Visual tabel of contents (VTOC) menggambarkan seluruh program HIPO (Hierarchy Plus InputProses-Output) baik rinci maupun ringkasan yang terstruktur. Pada diagram ini nama dan nomor dari program HIPO diitentifikasikan. Struktur paket diagram dan hubungan fungsi juga diidentifikasikan dalam bentuk hirarki. Keterangan masing-masing fungsi diberikan pada bagian penjelasan yang diikutsertakan dalam diagram ini. Visual tabel of contents simulasi tool sistem audit ini dapat digambarkan sebagai berikut: 


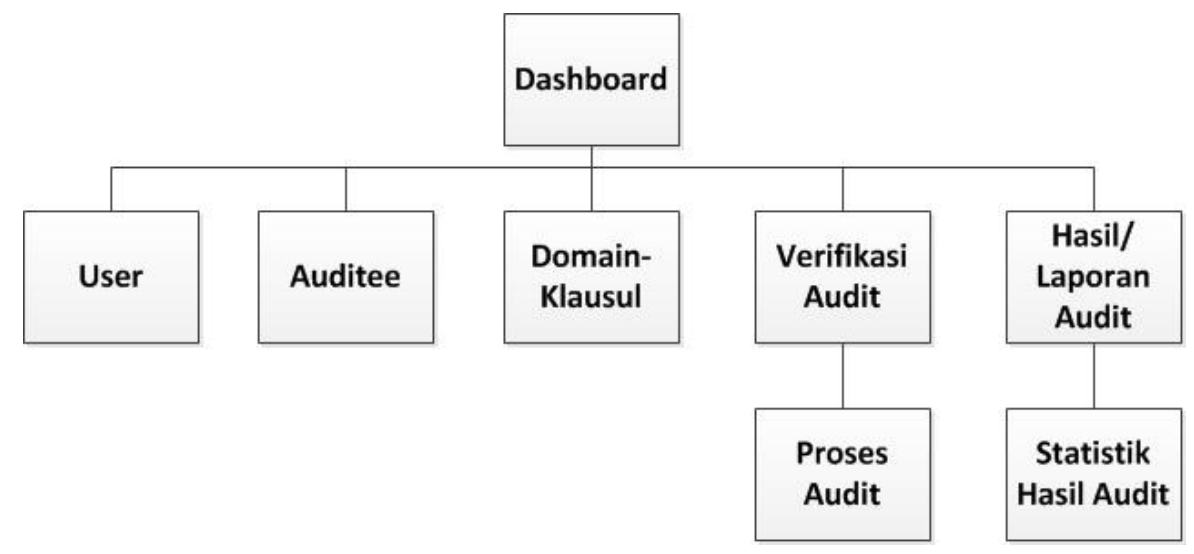

Gambar 3. VTOC Aplikasi Audit

\subsubsection{Flowchart Login}

Pada flowchart sistem Login dijelaskan admin atau auditor memasukkan username dan password. Jika sudah terverifikasi maka dapat langsung ke halaman utama

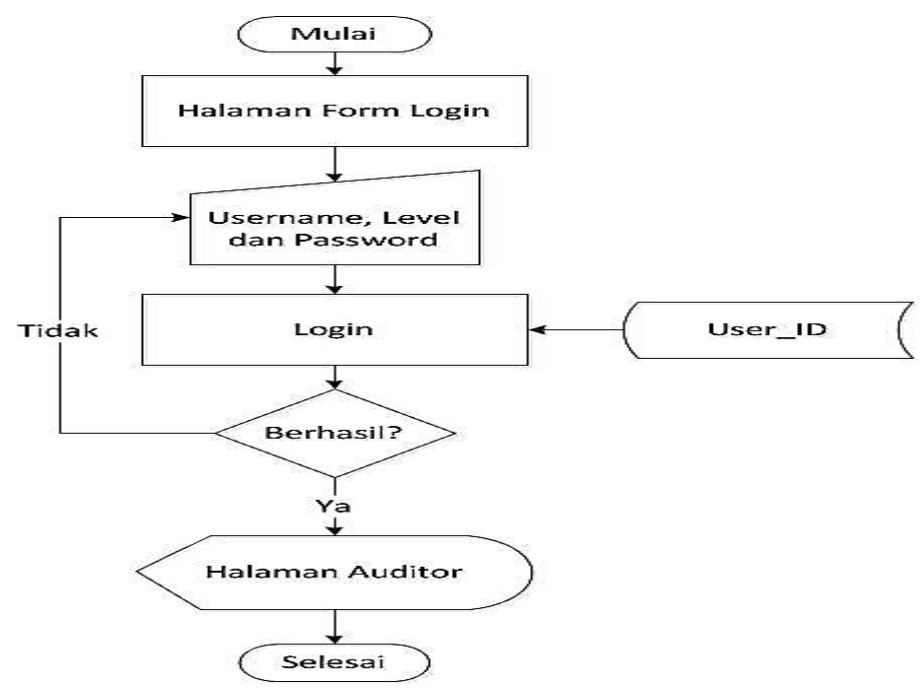

Gambar 4. Flowchart Sistem : Login

\subsubsection{Flowchart Audit TABK}

Pada flowchart sistem audit menjelaskan proses audit, mulai dari proses input data responden, proses hasil audit. 
JURSISTEKNI (Jurnal Sistem Informasi dan Teknologi Informasi) Vol 2, No.1, Januari 2020: Hal 46- 58 ISSN. P: 2715-1875, E: 2715-1883

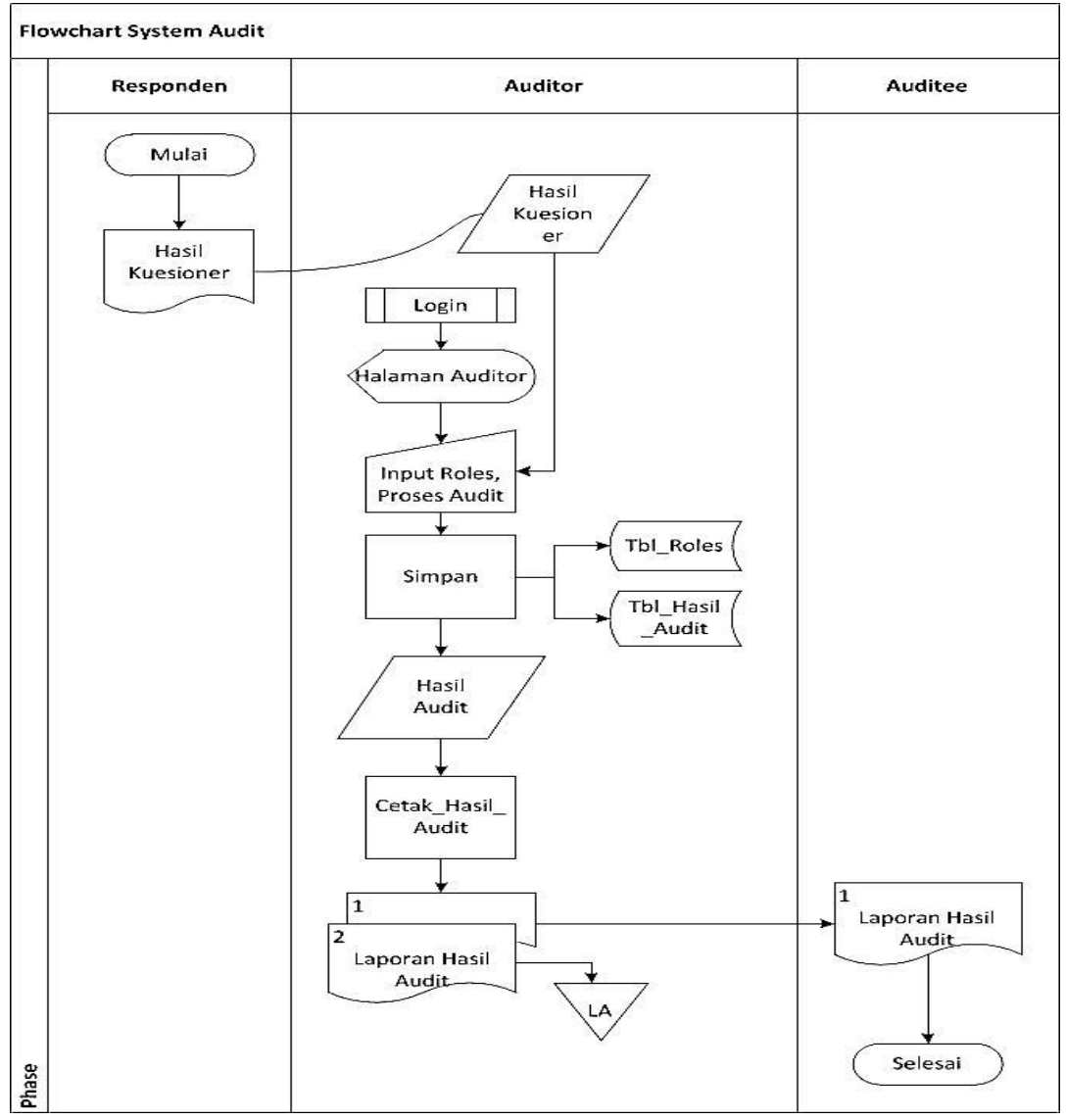

Gambar 5 Flowchart TABK

\subsection{Implementasi Sistem}

\section{a. Menu Login}

Halaman Login dengan hak akses yaitu sebagai Admin dan Auditor dengan level yaitu sebagai administrator dan pengguna.

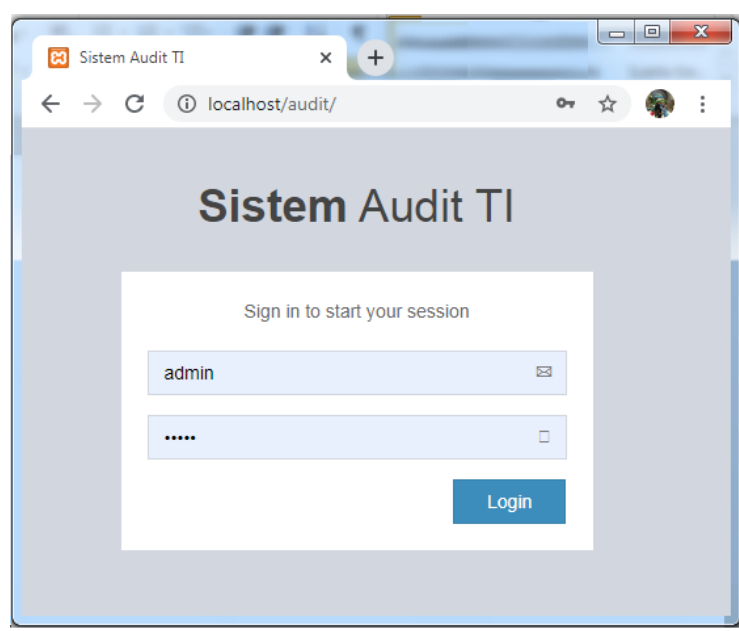

Gambar 6 Tampilan Login

\section{b. Halaman Dashboard}

Halaman dashboard merupakan halaman utama untuk mengakses menu berbagai aktivitas audit. 


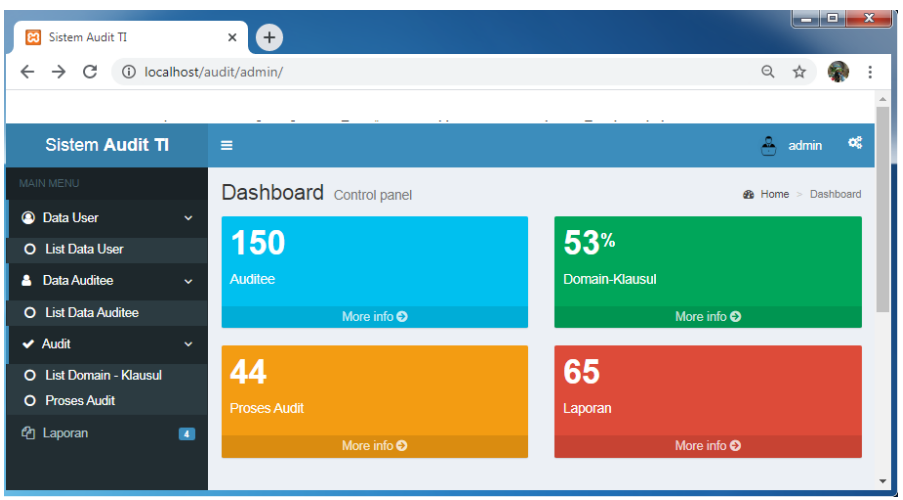

Gambar 7 Tampilan Dashboard

\section{c. Halaman Daftar User}

Halaman daftar user menampilkan daftar pengguna baik level administrator atau pengguna dan pengaturannya untuk melakukan koreksi.

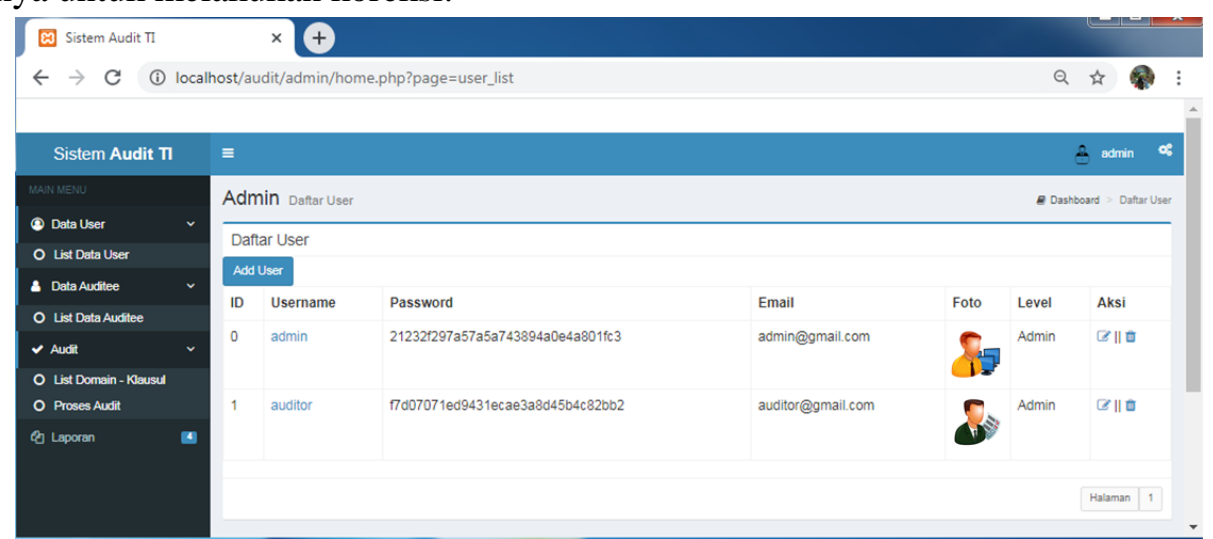

Gambar 8 Tampilan Daftar User

\section{d. Halaman Daftar Auditee}

Halaman daftar auditee menampilkan daftar auditee, dan pengaturannya untuk melakukan koreksi.

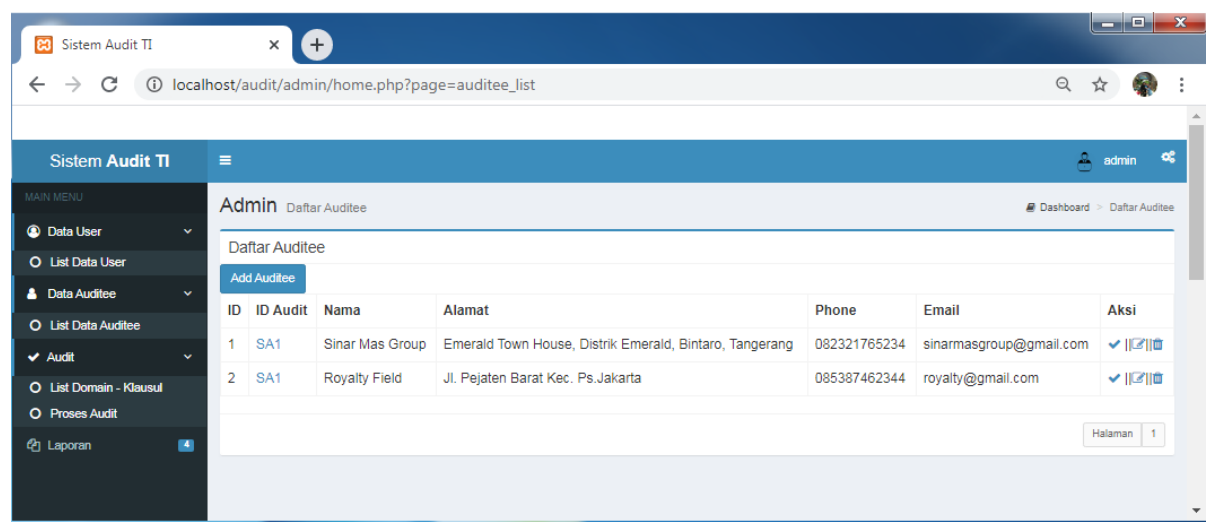

Gambar 9 Tampilan Daftar Auditee

\section{e. Halaman Daftar Domain - Klausul}

Halaman daftar domain-klausul menampilkan daftar domain-klausul dan pengaturannya untuk melakukan koreksi. 


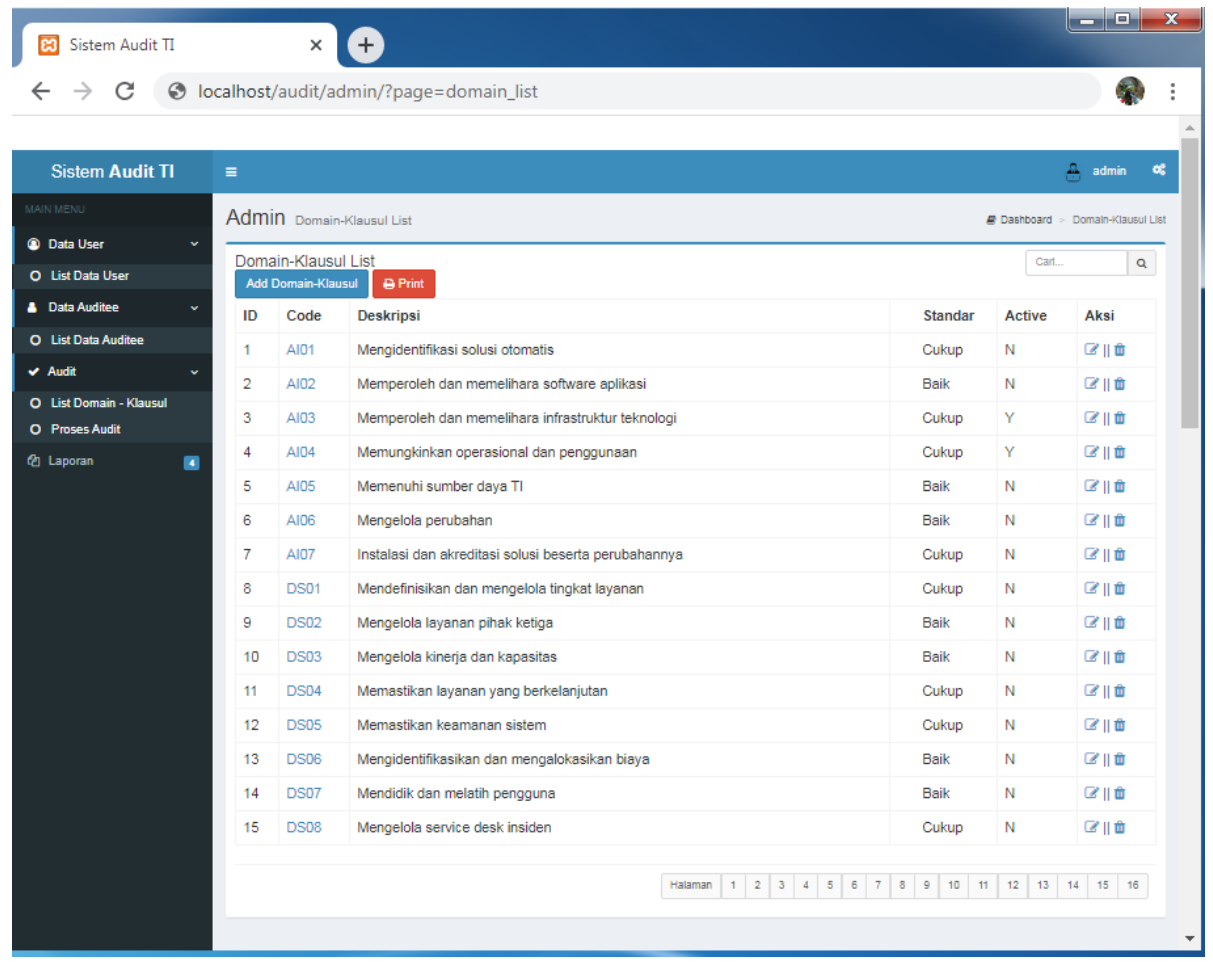

Gambar 10 Tampilan Daftar Domain-Klausul

\section{f. Halaman Input Data Domain-Klausul}

Halaman input data domain-klausul manampilkan formulir input data domain dan klausul.

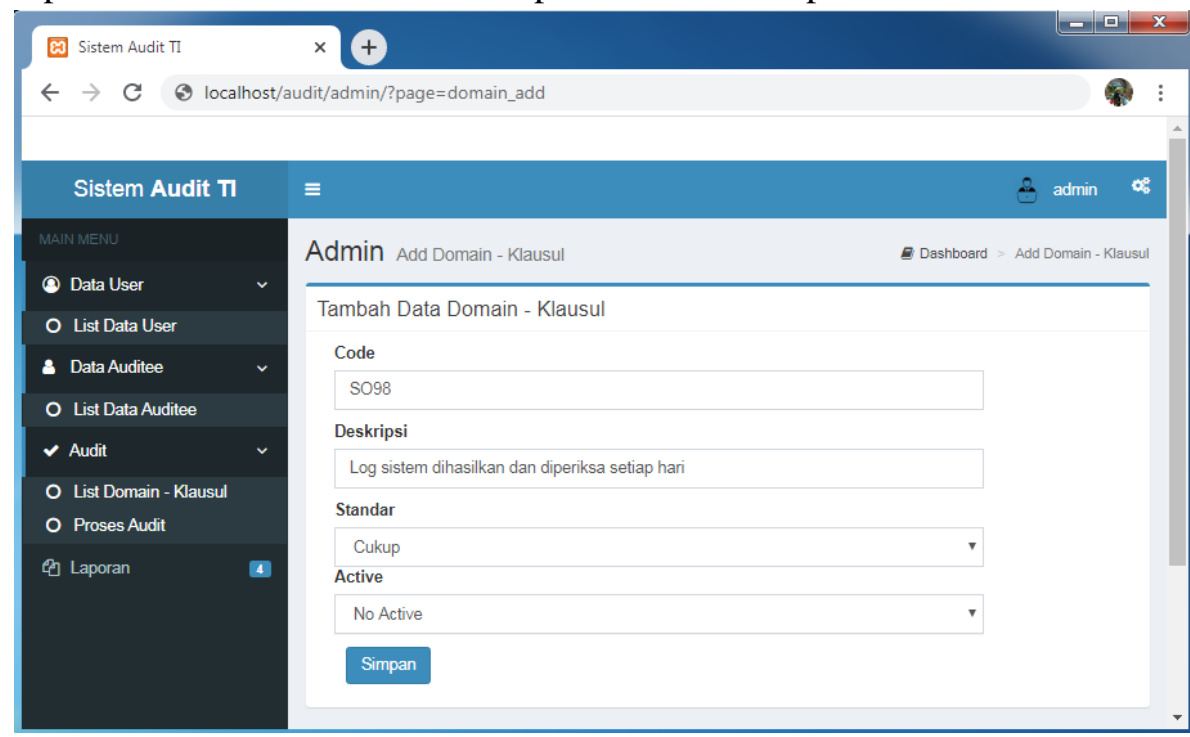

Gambar 11 Tampilan Input Domain-Klausul

\section{g. Halaman Proses Audit (Validasi Audit)}

Halaman proses audit berfungsi untuk melakukan validasi domain-klausus yang digunakan, standar mutu yang ditetapkan dan kondisi existing mutu. Selanjutnya dilakukan proses audit dengan menekan tombol "Audit", atau "Reset" untuk kembali ke pengaturan awal. 


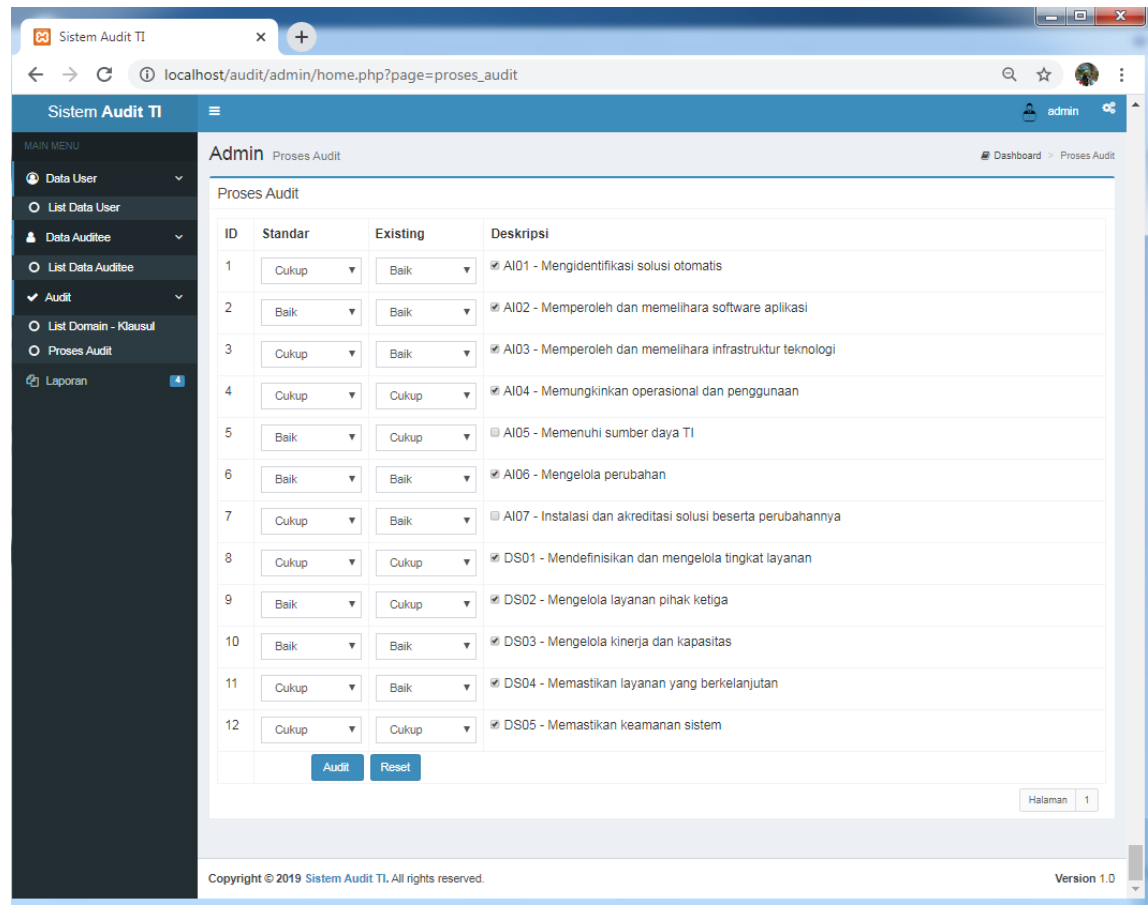

Gambar 12 Tampilan Input Domain-Klausul

\section{h. Halaman Hasil Audit}

Halaman Hasil Audit, menampilkan laporan hasil berdasarkan peroses audit yang dilakukan berdasarkan domain-klausul yang digunakan dan temuan.

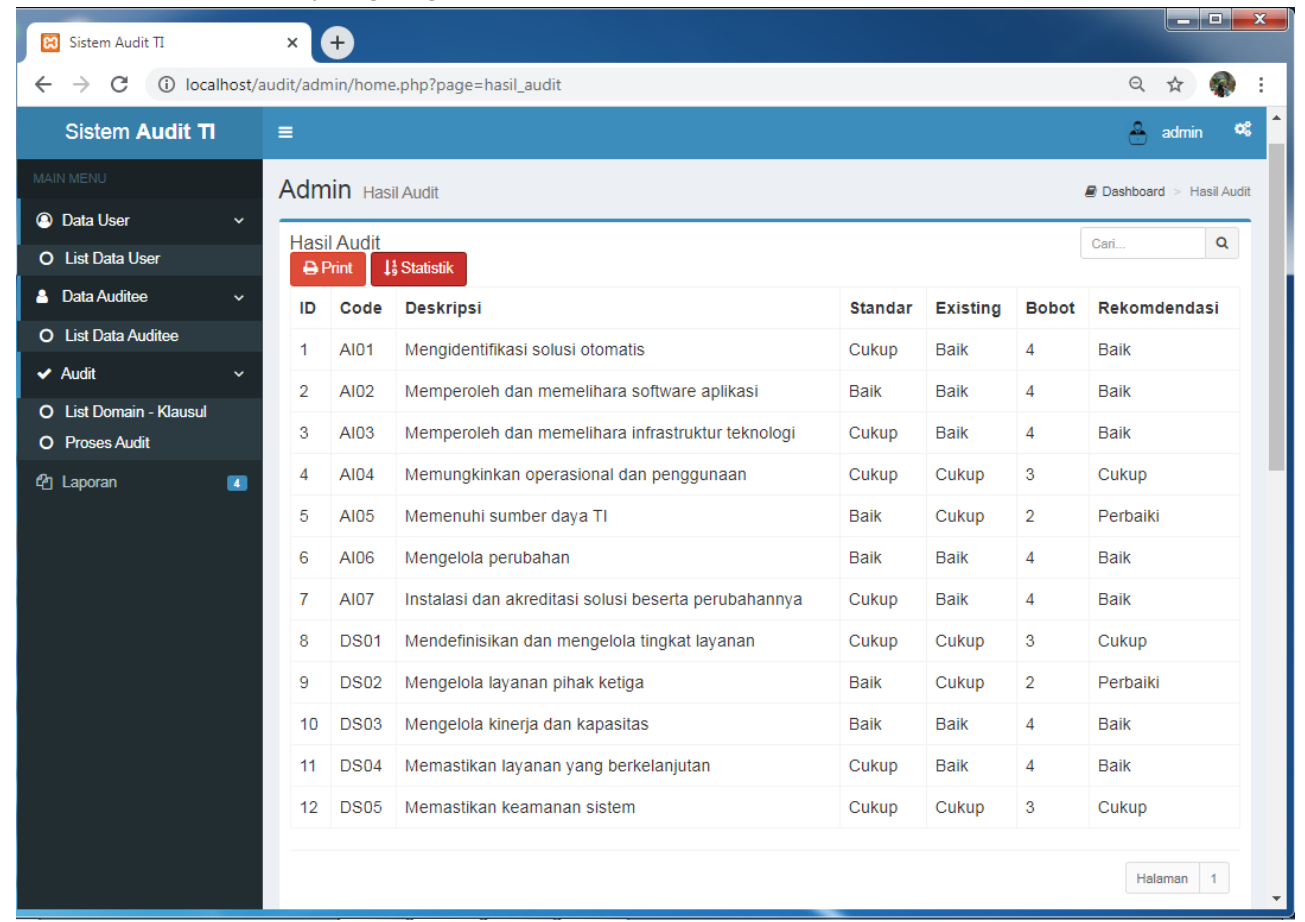

Gambar 13 Tampilan Input Domain-Klausul

\section{i. Halaman Hasil (Report-Statistik)}

Halaman statistik, menampilkan statistik berdasarkan hasil audit yang dilakukan. 


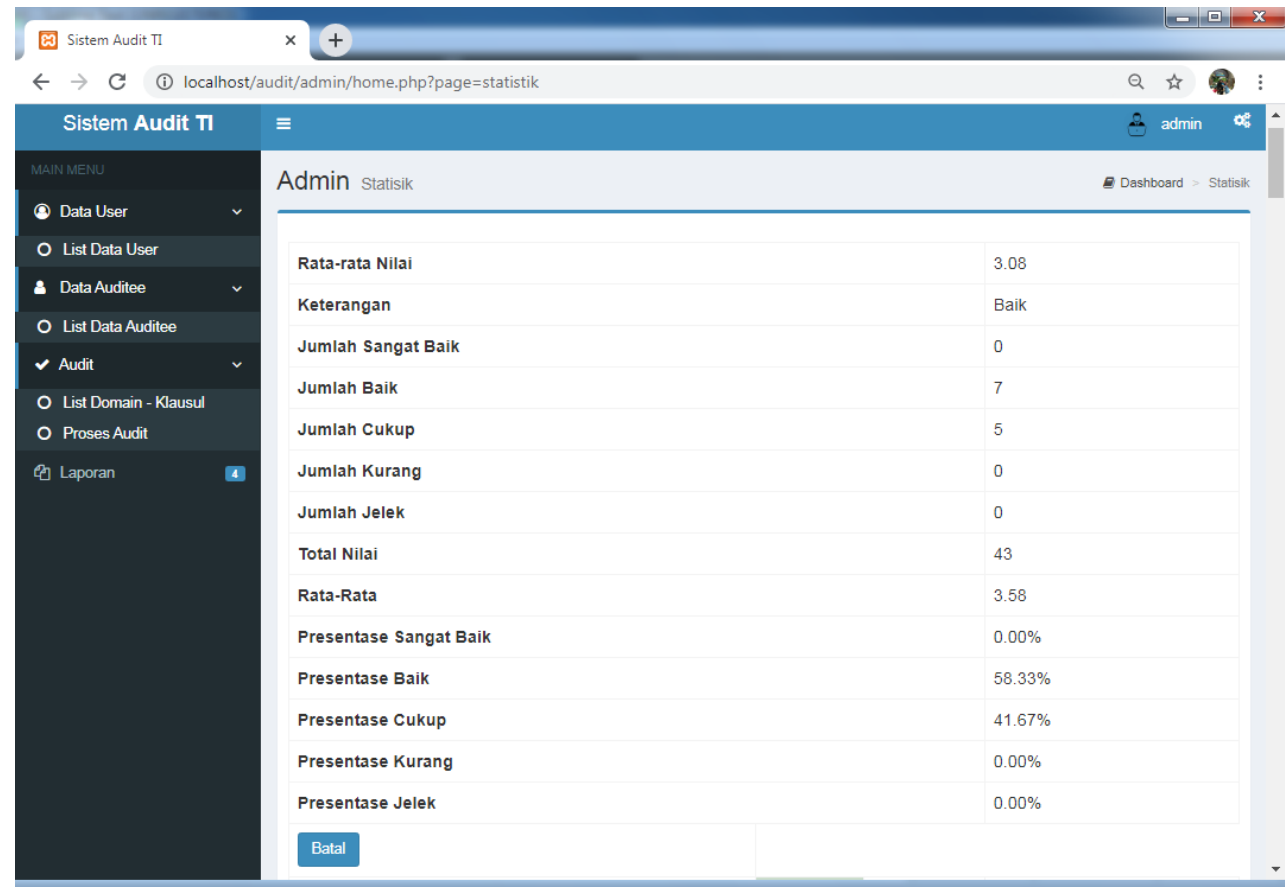

Gambar 14 Tampilan Input Domain-Klausul

\section{j. Pengujian Sistem}

Pada tahapan pengujian menggunakan teknik black-box dengan kasus uji dan hasil seperti pada Tabel 1 di bawah ini. Pengujian dilakukan pada setiap fungsionalitas di dalam tool sistem audit TI. Dari tabel 1 dapat dilihat bahwa keseluruhan fungsi yang diuji 100\% valid

Tabel 1. Skenario dan Hasil Pengujian

\begin{tabular}{|c|c|c|c|}
\hline Skenario & Test Case & $\begin{array}{c}\text { Hasil yang } \\
\text { Diharapkan }\end{array}$ & Status \\
\hline Berhasil Login & $\begin{array}{l}\text { User memasukkan Username dan password, } \\
\text { lalu menekan tombol "Login" }\end{array}$ & $\begin{array}{l}\text { User berhasil } \\
\text { "Login" ke } \\
\text { Tool Sistem } \\
\text { Audit TI. }\end{array}$ & Valid \\
\hline $\begin{array}{l}\text { Berhasil } \\
\text { menampilkan data } \\
\text { User }\end{array}$ & User memilih menu data User pada sidebar & $\begin{array}{l}\text { Daftar User } \\
\text { berhasil } \\
\text { ditampilkan. }\end{array}$ & Valid \\
\hline Berhasil add User & $\begin{array}{l}\text { User menekan tombol "Add User", } \\
\text { memasukkan data User, dan menekan } \\
\text { tombol "Simpan". }\end{array}$ & $\begin{array}{l}\text { Data User } \\
\text { berhasil } \\
\text { disimpan di } \\
\text { basis data. }\end{array}$ & Valid \\
\hline Berhasil edit User & $\begin{array}{l}\text { User memilih data User yang akan diedit } \\
\text { dengan menekan tombol "Edit User", } \\
\text { mengedit data dan menekan tombol } \\
\text { "Update". }\end{array}$ & $\begin{array}{l}\text { Data User } \\
\text { berhasil diubah } \\
\text { dan disimpan } \\
\text { kembali } \\
\text { dalam basis } \\
\text { data. } \\
\end{array}$ & Valid \\
\hline Berhasil hapus User & $\begin{array}{l}\text { User memilih data User yang akan dihapus } \\
\text { dengan menekan tombol "Edit User", } \\
\text { menghapus } \\
\text { data dengan menekan tombol "Delete". }\end{array}$ & $\begin{array}{l}\text { Data User } \\
\text { berhasil dihapus } \\
\text { dari basis data. }\end{array}$ & Valid \\
\hline $\begin{array}{l}\text { Berhasil } \\
\text { menampilkan data } \\
\text { auditee }\end{array}$ & $\begin{array}{l}\text { User memilih menu data auditee pada } \\
\text { "sidebar". }\end{array}$ & $\begin{array}{l}\text { Daftar auditee } \\
\text { berhasil } \\
\text { ditampilkan. }\end{array}$ & Valid \\
\hline
\end{tabular}




\begin{tabular}{|c|c|c|c|}
\hline Berhasil add auditee & $\begin{array}{l}\text { User menekan tombol "Add Auditee", } \\
\text { memasukkan data auditee, dan menekan } \\
\text { tombol "Save". }\end{array}$ & $\begin{array}{l}\text { Data auditee } \\
\text { berhasil } \\
\text { disimpan dibasis } \\
\text { data. }\end{array}$ & Valid \\
\hline Berhasil edit auditee & $\begin{array}{l}\text { User memilih data auditee yang akan diedit } \\
\text { dengan menekan tombol "Edit auditee", } \\
\text { mengedit data dan menekan tombol } \\
\text { "Update". }\end{array}$ & $\begin{array}{l}\text { Data auditee } \\
\text { berhasil diubah } \\
\text { dan disimpan } \\
\text { kembali dalam } \\
\text { basis data. }\end{array}$ & Valid \\
\hline $\begin{array}{l}\text { Berhasil hapus } \\
\text { auditee }\end{array}$ & $\begin{array}{l}\text { User memilih data auditee yang akan } \\
\text { dihapus dengan menekan tombol "Edit } \\
\text { auditee", menghapus data dengan menekan } \\
\text { tombol "Delete". }\end{array}$ & $\begin{array}{l}\text { Data auditee } \\
\text { berhasil dihapus } \\
\text { dari basis data. }\end{array}$ & Valid \\
\hline $\begin{array}{l}\text { Berhasil } \\
\text { menampilkan data } \\
\text { domain atau klausul }\end{array}$ & $\begin{array}{l}\text { User memilih menu Browse domain atau } \\
\text { klausul pada "sidebar". }\end{array}$ & $\begin{array}{l}\text { Daftar domain } \\
\text { atau klausul } \\
\text { berhasil } \\
\text { ditampilkan. }\end{array}$ & Valid \\
\hline $\begin{array}{l}\text { Berhasil input data } \\
\text { domain atau klausul }\end{array}$ & $\begin{array}{l}\text { User menginputkan kode domain atau } \\
\text { klausul beserta deskripsi, kemudian } \\
\text { menekan tombol simpan. }\end{array}$ & $\begin{array}{l}\text { Data berhasil } \\
\text { dimasukkan } \\
\text { ke basis data. }\end{array}$ & Valid \\
\hline $\begin{array}{l}\text { Berhasil edit data } \\
\text { domain atau klausul }\end{array}$ & $\begin{array}{l}\text { User memilih domain atau klausul yang } \\
\text { akan diedit dan mengedit data. }\end{array}$ & $\begin{array}{l}\text { Data di basis } \\
\text { data berhasil } \\
\text { diedit. }\end{array}$ & Valid \\
\hline $\begin{array}{l}\text { Berhasil hapus data } \\
\text { domain atau klausul }\end{array}$ & User menghapus data domain atau klausul & $\begin{array}{l}\text { Data berhasil } \\
\text { dihapus dari } \\
\text { basis data. }\end{array}$ & Valid \\
\hline $\begin{array}{l}\text { Berhasil validasi dan } \\
\text { deskripsi domain } \\
\text { atau klausul }\end{array}$ & $\begin{array}{l}\text { User melakukan proses validasi dengan } \\
\text { memilih pada menu pilihan standar, existing } \\
\text { dan checklist domain atau klausul, } \\
\text { kemudian menekan tombol proses audit }\end{array}$ & $\begin{array}{l}\text { Data hasil audit } \\
\text { dapat } \\
\text { ditampilkan dan } \\
\text { disimpan ke } \\
\text { basis data. }\end{array}$ & Valid \\
\hline Berhasil logout & $\begin{array}{l}\text { User menekan tombol "Logout" pada } \\
\text { "topmenu" }\end{array}$ & $\begin{array}{l}\text { User berhasil } \\
\text { logout dari } \\
\text { "Dashboard". }\end{array}$ & Valid \\
\hline
\end{tabular}

\section{KESIMPULAN}

Perancangan sistem pemilihan domain-klausul untuk audit teknologi informasi Berbasis pada domain-klausul framework audit. Simulasi tool sistem audit teknologi informasi yang dibangun mampu memberikan informasi data uji mengenai penilaian dan rekomendasi hasil audit.

\section{DAFTAR PUSTAKA}

[1] Gondodiyoto, S, Audit Sistem Informasi+Pendekatan CobIT (Edisi Revisi), Jakarta: Mitra Wacana Media, 2007.

[2] Roger S. Pressman, Rekayasa Perangkat Lunak Pendekatan Praktisi (Buku Satu), Yogyakarta: Andi, 2002.

[3] Sutabri, Tata., Konsep Sistem Informasi, Yogyakarta: Andi, 2012.

[4] Jogiyanto, Analisis \& Desain Sistem Informasi: Pendekatan Terstruktur Teori dan Praktik Aplikasi Bisnis, Yogyakarta: Andi, 2001.

[5] McLeod, R., Sistem Informasi Edisi 7 Jilid 2, Jakarta: Prenhallindo, 2001.

[6] Kristanto, A., Perancangan Sistem Informasi dan Aplikasinya, Jakarta: Gava Media, 2003. 
JURSISTEKNI (Jurnal Sistem Informasi dan Teknologi Informasi) Vol 2, No.1, Januari 2020: Hal 46- 58 ISSN. P: 2715-1875, E: 2715-1883

[7] Swastika, I Putu Agus dan I Gusti Lanang Agung Raditya Putra, Audit Sistem Informasi Dan Tata Kelola Teknologi Informasi: Implementasi Dan Studi Kasus. Yogyakarta: CV. Andi Offset, 2016.

[8] Wahyudi, D, Membangun situs menggunakan phpWebSite, Jakarta: Elex Media Komputindo, 2003.

[9] Al Fatta, Hanif, Analisis dan Perancangan Sistem Informasi untuk Keunggulan Bersaing. Yogyakarta: Andi, 2007. 